\title{
Screening of a Stable Cholesterol Oxidase for the Fabrication of Microbiosensor of Cholesterol by the Embodiment of Cholesterol Oxidase and a Platinized Platinum Electrode
}

\author{
Shigeru YAMAUCHI*, Masashi YAOITA, Ritsuko NAGAI ${ }^{\dagger}$, Yasuhiko YosHIDA' \\ and Yoshihito IKARIYAMA ${ }^{+}$ \\ Received June 29, 1990 ; Accepted August 20, 1990
}

\begin{abstract}
Microbiosensors for cholesterol having diameter of $100 \mu \mathrm{m}$ were fabricated by direct immobilization of cholesterol oxidases from different sources on a platinized platinum electrode. Among three cholesterol oxidases, the enzyme from Microorganism was stable to be used for a biosensor for cholesterol. The response current of the cholesterol sensor decreased gradually at $+0.6 \mathrm{~V}$ (vs.Ag/AgCl), however, reproducible and stable responses were obtained at $+0.5 \mathrm{~V}$. The response of the microbiosensor in the cholesterol determination was very rapid, and the time response was $20 \mathrm{~s}$. This sensor can be employed to the determination of cholesterol in the concentration range from $1.3 \mu \mathrm{M}$ to $52 \mu \mathrm{M}$.
\end{abstract}

\section{Introduction}

Determination of biochemical substances of diagnostic importance is indispensable in clinical analysis, which requires to determine not a few substances in one sampling. Furthermore, rapid determination is strongly needed in clinical laboratory. The authors believe that this is one of the backgrounds of the biosensor technology.

We have recently developed a novel microbiosensor, an enzyme embodied electrode (EEE) sensor. The sensor is fabricated by direct immobilization of enzyme on a platinized platinum electrode. ${ }^{1,2)}$ The fabrication technique of our microenzyme sepsor is based on the following two strategies; ${ }^{3)}$

(1) Direct immobilization of enzyme onto elec-

National Rehabilitation Center for the Disabled, Namiki 4-1, Tokorozawa, Saitama 359

†Dept. of Applied Chemistry, Faculty of Engineering, Toyo University, Kujirai 2100, Kawagoe, Saitama 350

$+\dagger$ Dept. of Bioengineering, Tokyo Institute of Technology, Ookayama 2-12-1, Meguro-ku, Tokyo 152

Key Words: microbiosensor for cholesterol, cholesterol oxidase, platinized platinum electrode trode surface. In other words a transducer doubles as a receptor.

(2) Employment of a platinized platinum electrode having a wide surface for immobilization of enough amount of enzyme. The microsensor thus fabricated offers efficient enzymatic and electrochemical reactions with fast response.

An EEE sensor is an amperometric detector of hydrogen peroxide. We have already reported that a platinized platinum electrode on which glucose oxidase is immobilized demonstrates high performance in glucose determination with high sensitivity and fast response. Another EEE sensor will exhibit similar characteristics provided that different oxidases as the sensor elements are employed.

In this paper, we describe the fabrication of a microsensor for cholesterol, since cholesterol determination is important in clinical chemistry. 4,5 ) Several amperometric cholesterol sensors have been reported, however, the response time of these sensors was still typically 2 or 3 min. ${ }^{6}-9$ ) A cholesterol sensor of fast response time has long been needed. Hence, we demonstrate the feasibility of the principle of EEE sensor to a cholesterol sensor by immobilizing $\mathrm{H}_{2} \mathrm{O}_{2}$-generating cholesterol oxidase on a miniaturized platinized platinum electrode. 


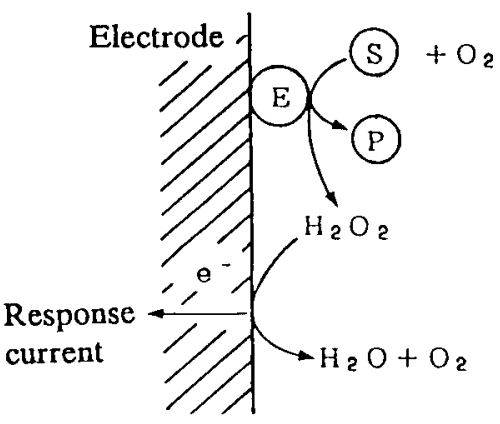

Fig. 1 Schematic illustration of cholesterol measurement with EEE sensor.

E: cholesterol oxidase, S: cholesterol, $P: \Delta^{4}$-cholesten-3-one

The principle of the EEE cholesterol sensor is shown in Fig. 1. When cholesterol contacts with cholesterol oxidase immobilized on a platinized platinum electrode whose potential is for $\mathrm{H}_{2} \mathrm{O}_{2}$ oxidation, the following enzymatic and electrochemical reactions occur simultaneously.

Cholesterol $+\mathrm{O}_{2} \longrightarrow \Delta^{4}$-cholesten-3-one $+\mathrm{H}_{2} \mathrm{O}_{2}$ $\mathrm{H}_{2} \mathrm{O}_{2} \longrightarrow \mathrm{O}_{2}+2 \mathrm{H}^{+}+2 \mathrm{e}^{-}$

The oxidation current for $\mathrm{H}_{2} \mathrm{O}_{2}$ is recorded as the sensor response in the amperometric microbiosensor. Due to the direct immobilization of enzyme, the sensor properties such as response time and sensitivity are the reflections of the enzyme immobilized.

In this paper, we discuss the characteristics of the EEE cholesterol sensors by immobilizing three types of cholesterol oxidases of different origins. We describe that one of them demonstrates as a noble bioelement of the EEE cholesterol sensor.

\section{Experimental}

A platinized platinum electrode having a diameter of $100 \mu \mathrm{m}$ was fabricated as described in the previous paper. 1) It was electrochemically deposited on a microelectrode under a constant potential of $-0.08 \mathrm{~V}$ (vs. $\mathrm{Ag} / \mathrm{AgCl}$ ) for $5 \mathrm{~min}$. Anodic polarization of the prepared platinized platinum electrode was performed at $+1.2 \mathrm{~V}$ for 15 min. ${ }^{10)}$ Enzyme incorporation was carried out by immersing the porous electrode in a $0.1 \mathrm{M}$ phosphate buffered solution ( $\mathrm{pH} 7.0$ ) containing cholesterol oxidase $(10 \mathrm{u} / \mathrm{ml})$ for $2 \mathrm{~h}$ at room temperature. We have taken three types of the enzyme. After immersion in each enzyme solution, every electrode was then immersed in a bovine serum albumin solution (5\%) for $10 \mathrm{~min}$ and in a glutaraldehide solution (1\%) for $10 \mathrm{~min}$ in this order for the preparation of thin protein layer over the micro enzyme electrode.

After overnight rinsing, the determination of cholesterol was performed with the enzyme electrode as a working electrode with an $\mathrm{Ag} / \mathrm{AgCl}$ electrode as a reference electrode. The oxidation of hydrogen peroxide generated by cholesterol oxidase was performed at a constant potential at $30{ }^{\circ} \mathrm{C}$ under stirring conditions. This stirring was performed to get limiting current. Triton X-100 was employed as the dispersion agent of cholesterol. In the preliminary examination, non-specific response of the platinized electrode for Triton X100 can be neglected, when samples were prepared in a phosphate buffered solution containing Triton $\mathrm{X}-100$, because electrode response to Triton X100 remained constant as long as the detergent concentration was between $0.01 \%$ and $0.3 \%$. The sample solutions of cholesterol were dispersed in $100 \mathrm{ml}$ phosphate buffered solution $(0.1 \mathrm{M}$, $\mathrm{pH} 7.0$ ) contained $0.2 \%$ Triton X-100.

\section{Results and Discussion}

\subsection{Screening of cholesterol oxidase as an element of cholesterol biosensing}

High enzyme activity is needed to get enough output response even after being immobilized onto a microelectrode whose surface is porous. Some enzymes may loose their activity in this immobilization process, which is the case of cholesterol oxidases. In general enzyme molecules are immobilized by adsorption onto platinum micro-particle surface, therefore, the quantity and activity of enzyme on electrode surface relate to the enzyme to be employed. However, some enzymes are fragile on the surface of noble metal surface such as platinum. We have selected three types of cholesterol oxidase as shown in Table 1 . After being immobilized the responses of these enzyme electrodes for cholesterol were studied in detail. Each enzyme was named as A (TOYOBO COO-311), B (Toyo Jozo T-04), and C (Toyo Jozo T-19).

The relation between the conditions of enzyme adsorption and the sensor response was investigated. Table 2 lists the response currents of the EEE cholesterol sensors immersed in each enzyme solution for $10 \mathrm{~min}$ or for overnight. Any difference in the responses of each sensor between 10 min and overnight adsorption with cholesterol oxidase from different source was not observed. 
Table 1 Characteristics of the employed cholesterol oxidase

\begin{tabular}{ccccccc}
\hline Enzyme & Origin and source & $\begin{array}{c}\text { Molecular } \\
\text { weight }\end{array}$ & $\begin{array}{c}\text { Stability range } \\
\text { in } \mathrm{pH}\end{array}$ & $\begin{array}{c}\text { Isoelectric point } \\
\text { Thermal } \\
\text { stability** }\end{array}$ & $\begin{array}{c}\text { Storage } \\
\text { stability** }\end{array}$ \\
\hline $\mathrm{A}$ & $\begin{array}{c}\text { Streptomyces sp. } \\
\text { (TOYOBO COO-311) }\end{array}$ & 34,000 & $\mathrm{pH} 5.0 \sim 10.0$ & $\mathrm{pH} 5.1$ and 5.4 & $45^{\circ} \mathrm{C}$ & $97 \%$ \\
$\mathrm{~B}$ & $\begin{array}{c}\text { Streptomyces cinnamomeus } \\
\text { (Toyo Jozo Enzyme T-04) } \\
\text { Microorganism }\end{array}$ & 38,000 & $\mathrm{pH} 6.1 \sim 8.5$ & $\mathrm{pH} 6.1$ and 7.3 & $40^{\circ} \mathrm{C}$ & $85 \%$ \\
$\mathrm{C}$ & 58,000 & $\mathrm{pH} 4.0 \sim 8.5$ & $\mathrm{pH} 4.8$ & $55^{\circ} \mathrm{C}$ & $100 \%$ \\
\hline
\end{tabular}

* Temperature at which activity starts to decrease

${ }^{* *}$ Activity remained after 3 months at $+5^{\circ} \mathrm{C}$

The effect of enzyme concentration was also studied, i.e., enzyme electrode was prepared in either $11.3 \mathrm{u} / \mathrm{ml}$ or $1021 \mathrm{u} / \mathrm{ml}$ of enzyme A. The resulting enzyme electrode demonstrated the same response of $0.34 \mathrm{nA}$ to $52 \mathrm{\mu M}$ cholesterol. From these results, we conclude that the adsorption of enzyme molecules to platinized platinum completed in a very short time even in a dilute solution of enzyme.

Figure 2 shows typical response curves for 13 uM $(0.5 \mathrm{mg} / \mathrm{dl})$ cholesterol determination at a potential of $+0.6 \mathrm{~V}$. Each response of the EEE sensor on which one of the enzymes was immobilized was $0.18 \mathrm{nA}, 0.18 \mathrm{nA}$, and $0.52 \mathrm{nA}$, respectively. The EEE sensor with the immobilized enzyme $C$ demonstrated the greatest response current. In every EEE sensor the response time was within $20 \mathrm{~s}$, although there were some slight differences among them.

As compared with a response time of the EEE sensor for glucose, the $100 \%$ response time of $3 \mathrm{~s}$ for glucose was faster than that of $20 \mathrm{~s}$ for cholesterol. Since cholesterol is incorporated in Triton X-100 micelles (M.W.; 90,000), it is estimated that the diffusion of cholesterol was slow in solution. However, the EEE cholesterol sensor fabricated here demonstrated a rapid response when compared with the response times of the conventional cholesterol sensors.

The difference in response current among three sensors for cholesterol may be the reflection of the enzyme utilized. The activity of each enzyme were determined colorimetrically. The absorption measurement was performed with phenol, 4aminoantipyrine, and horseradish peroxidase, and the results were shown in Table 2 . The measurement was carried out in the presence of $52 \mu \mathrm{M}$ cholesterol at $30^{\circ} \mathrm{C}$ in the $0.1 \mathrm{M}$ phosphate buffered solution of $\mathrm{pH} 7.0$ containing $0.2 \%$ Triton X100. Under this condition, the activity of enzyme $C$
Table 2 Effect of adsorption time to sensor response

\begin{tabular}{lccc}
\hline Enzyme & Activity* & \multicolumn{2}{c}{ Sensor response* } \\
\cline { 3 - 4 } & (p mol / min) & $10 \mathrm{~min}$ & Overnight \\
\hline $\mathrm{A}$ & 2.9 & 0.37 & 0.56 \\
$\mathrm{~B}$ & 4.7 & 0.28 & 0.21 \\
$\mathrm{C}$ & 114 & 1.88 & 1.98 \\
\hline
\end{tabular}

*The sensor responses and enzyme activity were measured for $52 \mu \mathrm{M}$ cholesterol.

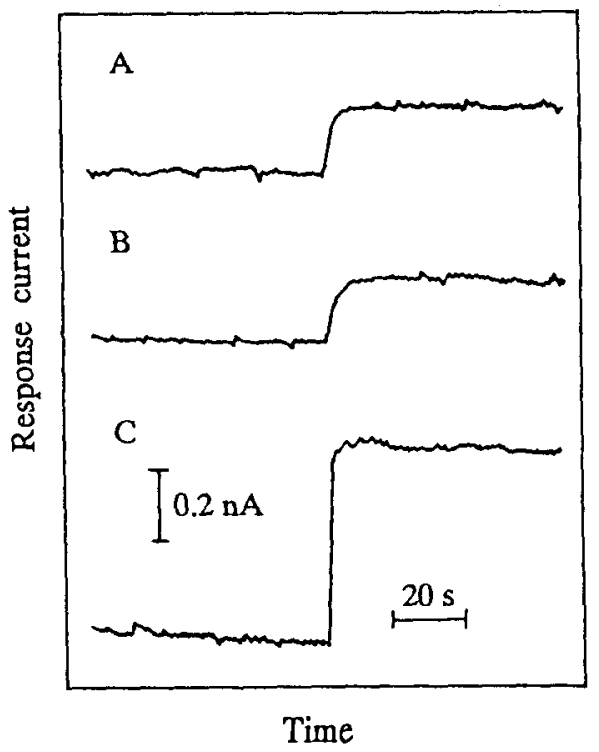

Fig. 2 Response curves of EEE sensors for $13 \mu \mathrm{M}$ cholesterol.

$A, B$, and $C$ represent the response curves of EEE cholesterol sensors of the respective enzyme. 
was the highest. These results suggest that the responses of the EEE sensor relate to the enzyme activity prepared in the phosphate buffered solution, however, sensor response was not directly proportional to the enzymatic activity. The sensor output current was proportional to cholesterol concentration from $1.3 \mu \mathrm{M}(50 \mu \mathrm{g} / \mathrm{dl})$ to $52 \mu \mathrm{M}(2.0$ $\mathrm{mg} / \mathrm{dl}$ ) at $0.5 \mathrm{~V}$.

\section{Characteristics of EEE cholesterol sensor}

Using an EEE sensor having largest response, prepared by immobilizing enzyme $\mathrm{C}$, typical characteristics of the EEE sensor for cholesterol was investigated. The sensor was operated at a potential of $+0.6 \mathrm{~V}$. When the sensor was repeated by used, a decrease of sensor response was observed. The response current in $13 \mu \mathrm{M}$ cholesterol sample was shown in Fig. 3. Inactivation of the enzyme at $+0.6 \mathrm{~V}$ may have been caused due to the electrochemical reaction at the interface between the enzyme molecules and particle surface. On the other hand, the sensor response at + $0.5 \mathrm{~V}$ was obtained for the comparison. The results are also shown in Fig. 3. At a potential of $+0.6 \mathrm{~V}$, the output current after the tenth measurement was $53 \%$ of the first response. Almost same response current of $0.35 \mathrm{nA}$ was detected even

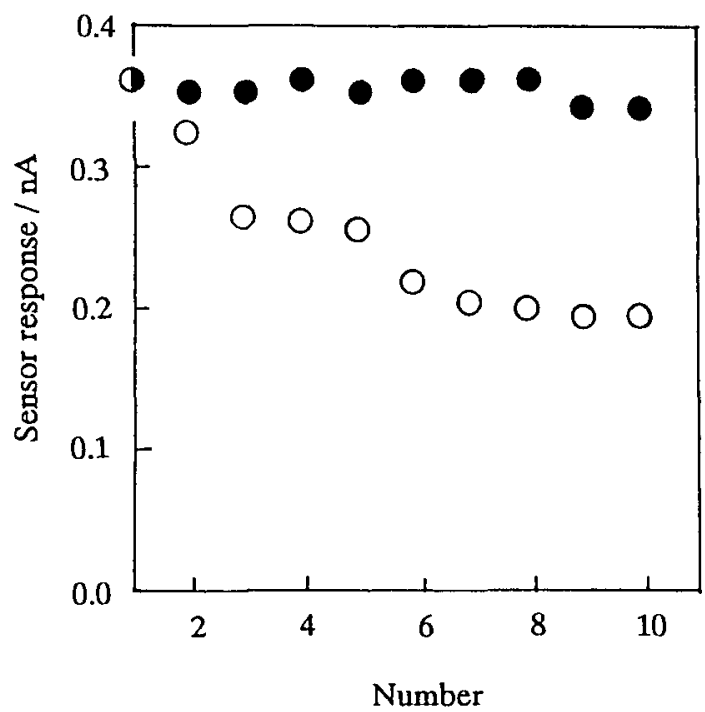

Fig. 3 Repeated measurement of EEE sensor for cholesterol.

Response current for $13 \mu \mathrm{M}$ cholesterol was detected under constant potentials of $+0.5 \mathrm{~V}(\bullet)$ and $+0.6 \mathrm{~V}(\mathrm{o})$ after the tenth measurement when the electrode potential was $+0.5 \mathrm{~V}$. Stable responses were obtained at a constant potential of $+0.5 \mathrm{~V}$, and the coefficient of variation was $2.3 \%$, when the number of measurement was 10 . However, the sensor response to cholesterol gradually decreased. The sensor output was $75 \%$ on the 20th day when the sensor was operated at $0.5 \mathrm{~V}$.

These results support our assumption that electrochemical inactivation of enzyme causes the decrease in sensor response. Enzyme may be inactivated by a slight change in $\mathrm{pH}$ due to the electrochemical reaction such as the oxidation of hydrogen peroxide. It is important to select a potential of the transducer electrode where enzyme suffers no damaging effect.

\section{Conclusion}

We demonstrated that EEE sensor technique was also applicable to the fabrication of a cholesterol sensor having high performance. Screening of enzyme is vital in the case of cholesterol oxidases, because some cholesterol oxidases loose their activity when they contact a potential-applied noble metal surface. It is suggested the technique can be applied to another oxidase as long as it generates hydrogen peroxide. EEE sensor technology will open avenues not only to high performance microbiosensor but to micromulti-biosensor.

\section{References}

(1) Y. Ikariyama, S. Yamauchi, T. Yukiashi, and H. Ushioda, Anal. Lett., 20., 1407 (1987).

(2) Y. Ikariyama, S. Yamauchi, M. Aizawa, T. Yukiashi, and H. Ushioda, Bull. Chem. Soc. Jpn., 61, 3525 (1988).

(3) S. Yamauchi, Y. Ikariyama, and M. Yaoita, "Chemical Sensor Technology Vol.2", Kodansha Ltd., 205 (1989).

(4) C. Bertrand, P.R. Coulet, and D.C. Gautheron, Anal. Lett., 12, 1477 (1979).

(5) S. Nomoto, Rinsyou Kensa, 20, 688 (1976).

(6) Y. Hahn and C.L. Olson, Anal. Chem., 51, 444 (1979).

(7) U. Wollenberger, F. Scheller, and P. Atrat, Anal. Lett., 13, 825 (1980).

(8) C. Bertrand, P.R. Coulet, and D.C. Gautheron, Anal. Chim. Acta, 126, 23 (1981).

(9) I. Karube, K. Hara, M. Matuoka, and S. Suzuki, Anal. Chim. Act, 139, 127 (1982).

(10) Y. Ikariyama, S. Yamauchi, T. Yukiashi, J. Electroanal. Chem., 251, 267 (1988). 